\title{
Alginate/Pluronic F127-based encapsulation supports viability and functionality of human dental pulp stem cell-derived insulin-producing cells
}

Suryo Kuncorojakti ${ }^{1,2}$, Watchareewan Rodprasert2 ${ }^{2}$, Supansa Yodmuang ${ }^{3,4}$, Thanaphum Osathanon ${ }^{5,6}$, Prasit Pavasant ${ }^{5,6}$, Sayamon Srisuwatanasagul ${ }^{7 *}$ and Chenphop Sawangmake $2,8,9^{*}$ (D)

\begin{abstract}
Background: Current approach for diabetes treatment remained several adverse events varied from gastrointestinal to life-threatening symptoms. Regenerative therapy regarding Edmonton protocol has been facing serious limitations involving protocol efficiency and safety. This led to the study for alternative insulin-producing cell (IPC) resource and transplantation platform. In this study, evaluation of encapsulated human dental pulp-derived stem cell (hDPSC)-derived IPCs by alginate (ALG) and pluronic F127-coated alginate (ALGPA) was performed.

Results: The results showed that ALG and ALGPA preserved hDPSC viability and allowed glucose and insulin diffusion in and out. ALG and ALGPA-encapsulated hDPSC-derived IPCS maintained viability for at least $336 \mathrm{~h}$ and sustained pancreatic endoderm marker (NGN3), pancreatic islet markers (NKX6.1, MAF-A, ISL-1, GLUT-2 and INSULIN), and intracellular pro-insulin and insulin expressions for at least 14 days. Functional analysis revealed a glucoseresponsive C-peptide secretion of ALG- and ALGPA-encapsulated hDPSC-derived IPCS at 14 days post-encapsulation. Conclusion: ALG and ALGPA encapsulations efficiently preserved the viability and functionality of hDPSC-derived IPCs in vitro and could be the potential transplantation platform for further clinical application.
\end{abstract}

Keywords: Insulin-producing cells (IPCs), Dental pulp stem cells (DPSCs), Diabetes mellitus, Encapsulation, Alginate, Pluronic F127

\section{Background}

Diabetes mellitus is an intractable metabolic disease. Epidemiological studies covering 2.7 million of participants during 1980-2008 reported the global increases of glycemia and diabetes prevalence which were correlated

\footnotetext{
* Correspondence: sayamon.@@chula.ac.th; sayamon@gmail.com; chenphop.s@chula.ac.th; chenphop@gmail.com

${ }^{7}$ Department of Veterinary Anatomy, Faculty of Veterinary Science,

Chulalongkorn University, Bangkok 10330, Thailand

${ }^{2}$ Veterinary Stem Cell and Bioengineering Innovation Center (VSCBIC),

Veterinary Pharmacology and Stem Cell Research Laboratory, Faculty of Veterinary Science, Chulalongkorn University, Bangkok 10330, Thailand Full list of author information is available at the end of the article
}

with population growth and ageing [1]. Moreover, the global prevalence of diabetes is expected to be 693 million in all age-group worldwide by 2045 [2]. Several approaches have been clinically introduced to manage hyperglycemic conditions and consequence complications i.e. exogenous insulin and pharmacotherapeutic preparations [3]. However, there were some reports suggested an evidence of hypoglycemia and adverse events [4]. From these reasons, many of researchers have been trying in finding novel approach to cope diabetes and its complications. In 2000, the first human islet transplantation according to Edmonton protocol has

(c) The Author(s). 2020 Open Access This article is licensed under a Creative Commons Attribution 4.0 International License, which permits use, sharing, adaptation, distribution and reproduction in any medium or format, as long as you give appropriate credit to the original author(s) and the source, provide a link to the Creative Commons licence, and indicate if changes were made. The images or other third party material in this article are included in the article's Creative Commons licence, unless indicated otherwise in a credit line to the material. If material is not included in the article's Creative Commons licence and your intended use is not permitted by statutory regulation or exceeds the permitted use, you will need to obtain permission directly from the copyright holder. To view a copy of this licence, visit http://creativecommons.org/licenses/by/4.0/. The Creative Commons Public Domain Dedication waiver (http://creativecommons.org/publicdomain/zero/1.0/) applies to the data made available in this article, unless otherwise stated in a credit line to the data. 
been proposed [5]. However, there were some limitations i.e. adverse events of immunosuppressants, limited availability of donors, and limited duration of insulin independent period [6]. By the limitations of Edmonton protocol, trend of stem cell-based therapy has been announced as a candidate and promising protocol for diabetes treatment.

Various types of pluripotent stem cells have been employed for generation of insulin-producing cells (IPCs) in vitro. Derivation from mouse and human embryonic stem cells (ESCs) has been reported [7, 8], unfortunately, the ethical and tumorigenicity issue might hamper for the clinical application [9]. To address this problem, current plethora of studies are mainly focused on mesenchymal stem cells (MSCs) [10]. Various types of MSCs have been used for generation of IPCs in vitro i.e. human and mouse bone marrow-derived MSCs (BM-MSCs) [11]. Dental tissue-derived MSCs also can be proposed as an alternative source, in vitro generation of IPCs was firstly achieved by using MSCs isolated from SHED or stem cell from human exfoliated deciduous teeth [12]. Another study also reported that the human dental pulp stem cells (hDPSCs) had a good potency for in vitro differentiation toward IPCs [13]. Besides, hDPSCs have been proposed as the alternative stem cell resource due to their accessibility and availability [14, 15]. Furthermore, the advantages of hDPSC have been reported by several investigators i.e. the multilineage differentiation potential, the capacity for autologous and allogenic transplantation [16], the abundance in source and less ethical issue both in research and clinical translation [17].

Another challenge of cell-based therapy for translational study and clinical application is how to maintain the viability and functionality of the IPCs. Encapsulation can be applied to address this challenge due to the ability on rejection avoiding $[18,19]$. Alginate is a material that widely used in biomedical field, drug delivery and tissue engineering [20], since it provides advantages i.e. less difficulties for application, effective immunobarrier activity [21] and cell viability support [20]. To avoid the cell protrusion that can lead rejection, multilayer encapsulation can be applied [22]. Pluronic F127, a synthetic and thermosensitive polymer can be used as a coating material of alginate due to their special characteristic i.e. showing non-toxicity, enhancing cell adhesion, supporting collagen production and promoting angiogenesis [23].

Currently, the application of multilayer encapsulation that incorporates alginate and pluronic F127 for stem cell-based diabetes therapy is not well established. This led to the pitfall of knowledge and opportunity for treating intractable disease. Therefore, this study is aimed to establish and validate the suitable encapsulation platform for IPCs in vitro, by using the hDPSC-derived IPCs. This knowledge will support the success of in vivo transplantation study which is critical for further clinical protocol establishment.

\section{Results \\ Alginate/pluronic F127-based encapsulation supports viability of hDPSCs}

For serving the IPC encapsulation, the diameter of needle plays an important role. Figure 1 visualized the effect of different size of needle (22G, 24G and 26G) on the diameter of the beads. The measurement of diameter was assessed at day 0, 7, 14 and 28. As shown in Fig. 1, manual extruding protocol using different needle size resulted in different size of beads diameter. At day 0 there is no significant difference on beads diameter produced from all different size of needle between alginate (ALG) and pluronic F127 coated alginate (ALGPA) encapsulation. The 22G needle resulted in the highest diameter in both encapsulation platform, respectively $2732.27 \pm 44.62 \mathrm{~mm}$ and $2770.16 \pm 34.08 \mathrm{~mm}$ for ALG and ALGPA, while $26 \mathrm{G}$ resulted in the lowest diameter size, $2355.22 \pm 32.41 \mathrm{~mm}$ and $2379.70 \pm 70.44 \mathrm{~mm}$ for ALG and ALGPA. Similar trend was also shown in day 7, 14 and 28 but significant differences of diameter were noted between ALG and ALGPA encapsulation. In the end of experiment the percentage swelling of both encapsulations were $2.61-4.50 \%$ and $7.64-10.91 \%$ for ALG and ALGPA respectively. The swelling percentage was assessed by calculating the percentage of final diameter at day 28 minus initial diameter at day 0 , then compared to the baseline (diameter at day 0 ).

To evaluate diffusion ability of ALG and ALGPA, modified transwell diffusion assay was performed. Figure 2a showed the glucose diffusion in both encapsulation platform, after $60 \mathrm{~min}$ incubation. The percentage of glucose diffusion were $62.90-76.10 \%$ and $64.50-78.40 \%$ for ALG and ALGPA respectively. These results were significantly different compared to the baseline at 15 min. As shown in Fig. 2b, the percentage of insulin diffusion in ALG and ALGPA encapsulation after $60 \mathrm{~min}$ of incubation were $44.00-54.40 \%$ and $48.00-61.90 \%$ respectively which was significantly different $(p<0.05)$.

Visualization of encapsulated hDPSC morphology under inverted microscope showed that the hDPSCs were dispersed into single cells inside the alginate capsule (Fig. 3a). Viability assessment of post-encapsulated hDPSCs was performed by quantitative method of alamarBlue $^{\mathrm{Tn}}$ assay and live/dead staining. As metabolic activity of hDPSCs was assessed by alamarBlue ${ }^{\mathrm{rm}}$ assay, Fig. 3b showed that the metabolic activity of hDPSCs in both encapsulations were slightly increase at 24-96 h post encapsulation and tend to be stable until $336 \mathrm{~h}$. Consistent results were visualized in Fig. 3c which 


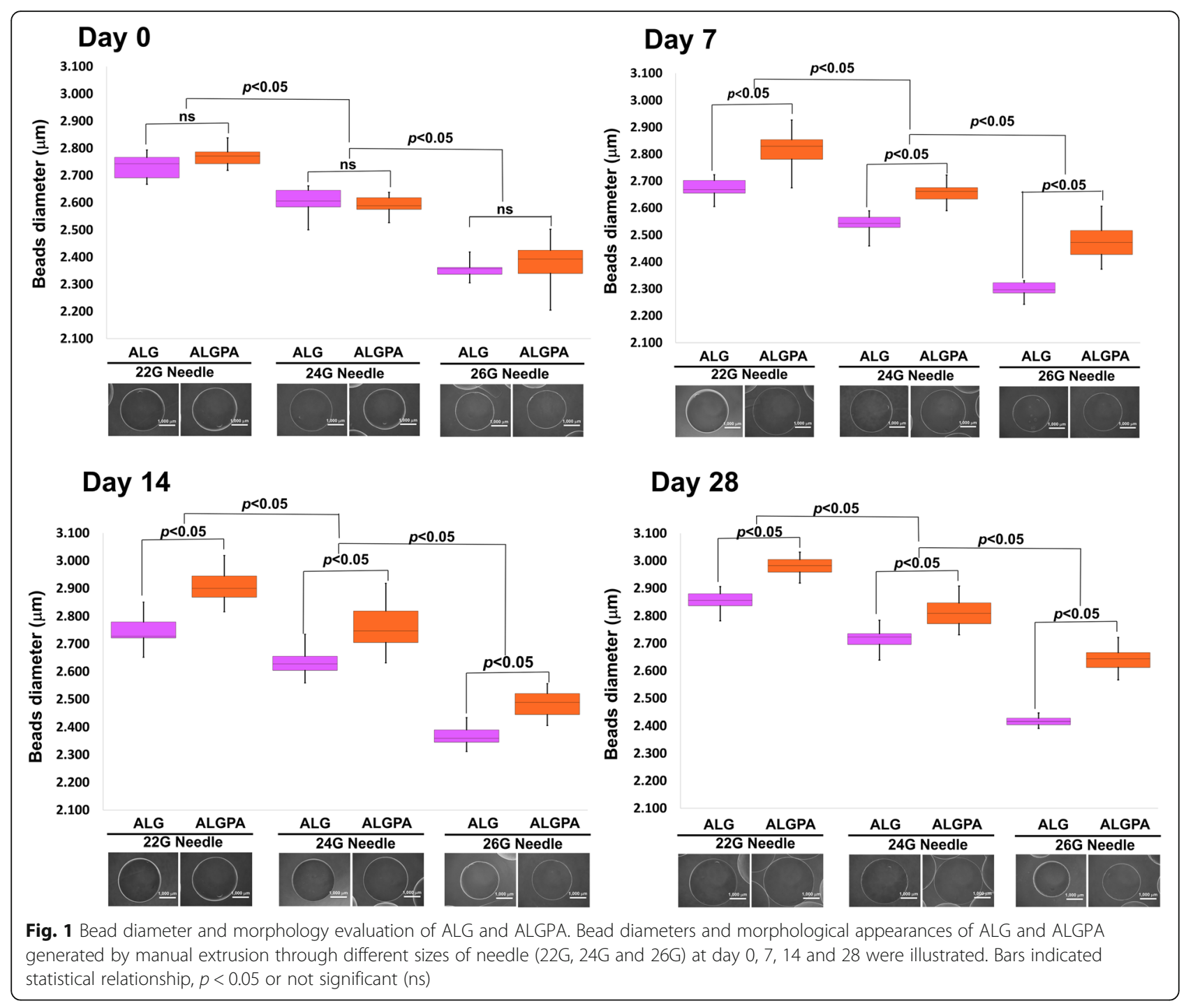

encapsulated hDPSCs were stained by live/dead staining kit. All cells were stained by DAPI and the dead cells were stained by propidium iodide (PI) resulted in blue and red fluorescence, respectively. Only few numbers of dead cells were found at $336 \mathrm{~h}$ post-encapsulation.

\section{hDPSC characterization}

hDPSCs were characterized before undergone IPC induction. Morphological assessment of hDPSCs under normal culture medium were performed. Plastic adherent and fibroblastic cells were observed from hDPSCs used in this experiment (Fig. 4a). In addition, RT-qPCR was employed to analyse the expression of stemness and proliferative genes. The results showed that the stemness genes (REX1, NANOG and OCT4) and proliferative gene (Ki67) were expressed by hDPSCs (Fig. 4b). The surface markers of hDPSCs were determined by using flow cytometry. Several mesenchymal stem cell surface markers
CD90, CD73 and CD44 were strongly expressed. However, CD105 expression was relatively lower in hDPSCs. Furthermore, CD45 surface marker expression in hDPSCs were extremely low (Fig. 4c).

\section{In vitro differentiation of hDPSCs toward IPCs}

Ten-day induction protocol was employed in this experiment. Initial differentiation was observed at day 3 , where the single cell suspension of hDPSCs at day 0 were changed into cell aggregates. Further, the development of cell aggregates were clearly noted at day 5 , day 7 and day 10 . In the end of the induction protocol, big and dense cell aggregates were observed (Fig. 5a). The total colony count of cell aggregates obtained from this experiment were 424-581 colonies in which $60.68-74.70 \%$ had diameter more than $100 \mu \mathrm{m}(100.81-303.43 \mu \mathrm{m})$, while small colonies (diameter less than $50 \mu \mathrm{m}$ ) were only $1.55-12.10 \%$ (Fig. $5 \mathrm{~b}$ and $\mathrm{c}$ ). The results were further 

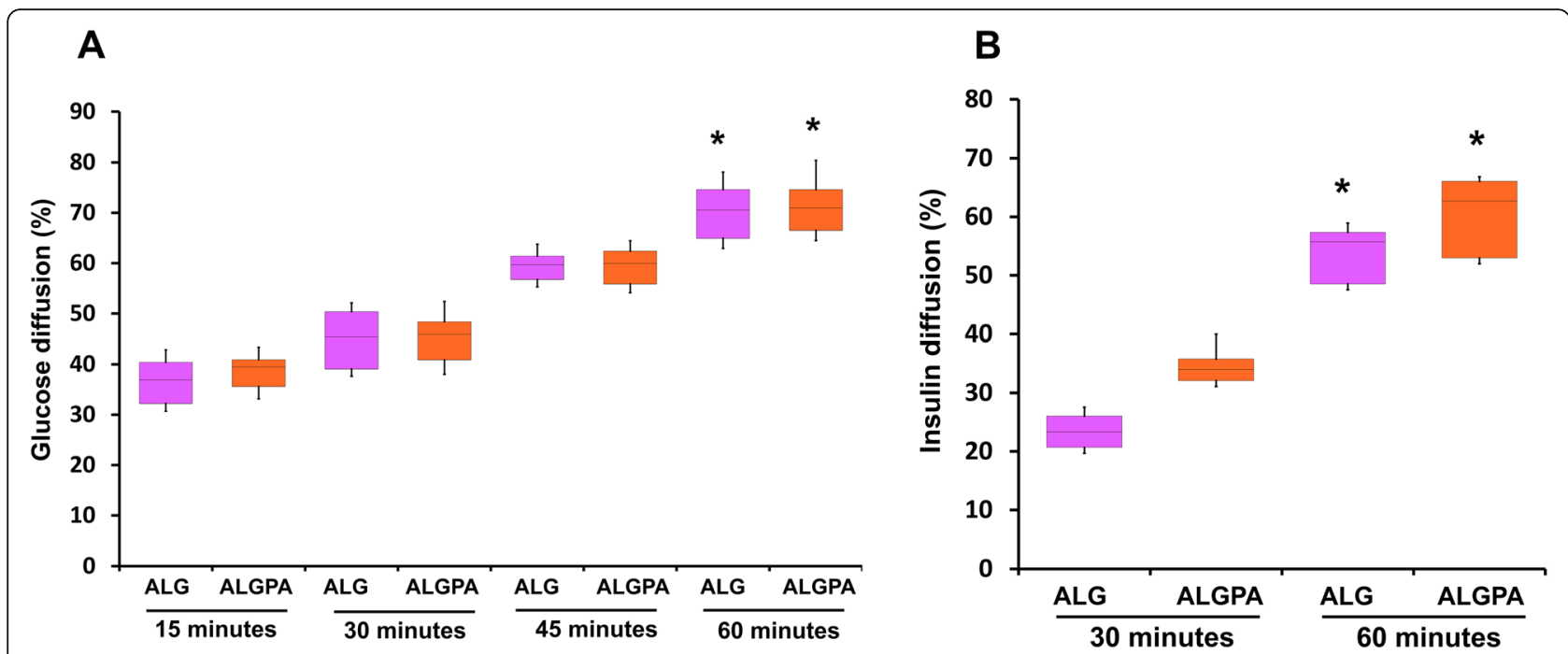

Fig. 2 Glucose and insulin diffusion efficiency of ALG and ALGPA. The percentages of glucose diffusion $\mathbf{a}$ and insulin diffusion $\mathbf{b}$ across ALG and ALGPA as determined by modified trans-well diffusion assay were illustrated. The asterisks indicated significant difference, comparing with the initial condition at $15 \mathrm{~min}$ (glucose diffusion) and $30 \mathrm{~min}$ (insulin diffusion) $(p<0.05)$

analyzed by immunocytochemistry staining (Fig. 5d) and it was showed that cell aggregates derived from hDPSCs expressed both intracellular pro-insulin and insulin.

\section{In vitro viability evaluation of alginate/pluronic F127- based encapsulation of hDPSC-derived IPCs}

Microscopic observation of encapsulated hDPSC-derived IPCs in both encapsulation platform was performed (Fig. $6 a)$. The findings showed that cell aggregates derived from hDPSCs were unequally dispersed into the alginate beads. Cell aggregate damage was not observed. Further analysis to evaluate the viability of encapsulated hDPSCderived IPCs was done by using live/dead staining (Fig. 6b). Post encapsulation staining showed that hDPSCderived IPCs were survive at least $336 \mathrm{~h}$. However, small mass of non-viable cells was observed in the core of encapsulated cell aggregates.

\section{Alginate/pluronic F127-based encapsulation maintains functionality of hDPSC-derived IPCs in vitro}

Post-encapsulation evaluation of hDPSC-derived IPCs was performed by RT-qPCR to analyse the expression of pancreatic endoderm, pancreatic islet and pancreatic related genes. Encapsulated hDPSC-derived IPCs in ALG and ALGPA expressed pancreatic endoderm gene marker (NGN3) at day 7 and day 14 post encapsulation (Fig. 7a). The expression of pancreatic islet genes was noted at day 7 and 14. NKX6.1, MAF-A, ISL-1, GLUT-2 and INSULIN genes were expressed in encapsulated hDPSC-derived IPCs in both ALG and ALGPA (Fig. 7b). Further, at day 7 and 14 in both encapsulation platform, the pancreatic-related gene, GLP-1R, was detected, while the expression of GLUCAGON gene was not significantly different compared to undifferentiated cells (Fig. 7c). All gene expression patterns regarding pancreatic endoderm, pancreatic islet and pancreatic-related genes of encapsulated hDPSC- derived IPCs were not significantly different compared to initial IPC condition before encapsulation.

Immunocytochemistry staining was employed to confirm the results. hDPSC-derived IPCs were stained before and after encapsulation ( 7 and 14 days). Figure $8 \mathrm{a}$ visualized that in both encapsulation by ALG and ALGPA, intracellular pro-insulin and insulin were expressed at day 7 and 14 post-encapsulation. The similar expression of intracellular pro-insulin and insulin also was observed in hDPSC-derived IPCs at the initial condition (before encapsulation).

In vitro evaluation regarding the function of encapsulated hDPSC-IPCs was assessed by using glucosestimulated C-peptide secretion (GSCS) assay. The results of this experiments were compared with the initial condition of hDPSC-derived IPCs (before encapsulation). At day 14 post-encapsulation, hDPSC-derived IPCs in both ALG and ALGPA were challenged with three different condition, normal KRBH, $5.5 \mathrm{mM}$ and $22 \mathrm{mM}$ glucose in $\mathrm{KRBH}$. The result showed that C-peptide was secreted by hDPSC-derived IPCs in both ALG and ALGPA encapsulation conditions after incubated with $22 \mathrm{mM}$ glucose in KRBH. This result was significantly different compared to the C-peptide secreted in normal KRBH and $5.5 \mathrm{mM}$ glucose in $\mathrm{KRBH}$ conditions, suggesting trend of glucose-responsive function. In this study, no significant difference was observed regarding the in vitro functional evaluation of hDPSC-derived IPCs before and after encapsulation (Fig. 8b). 


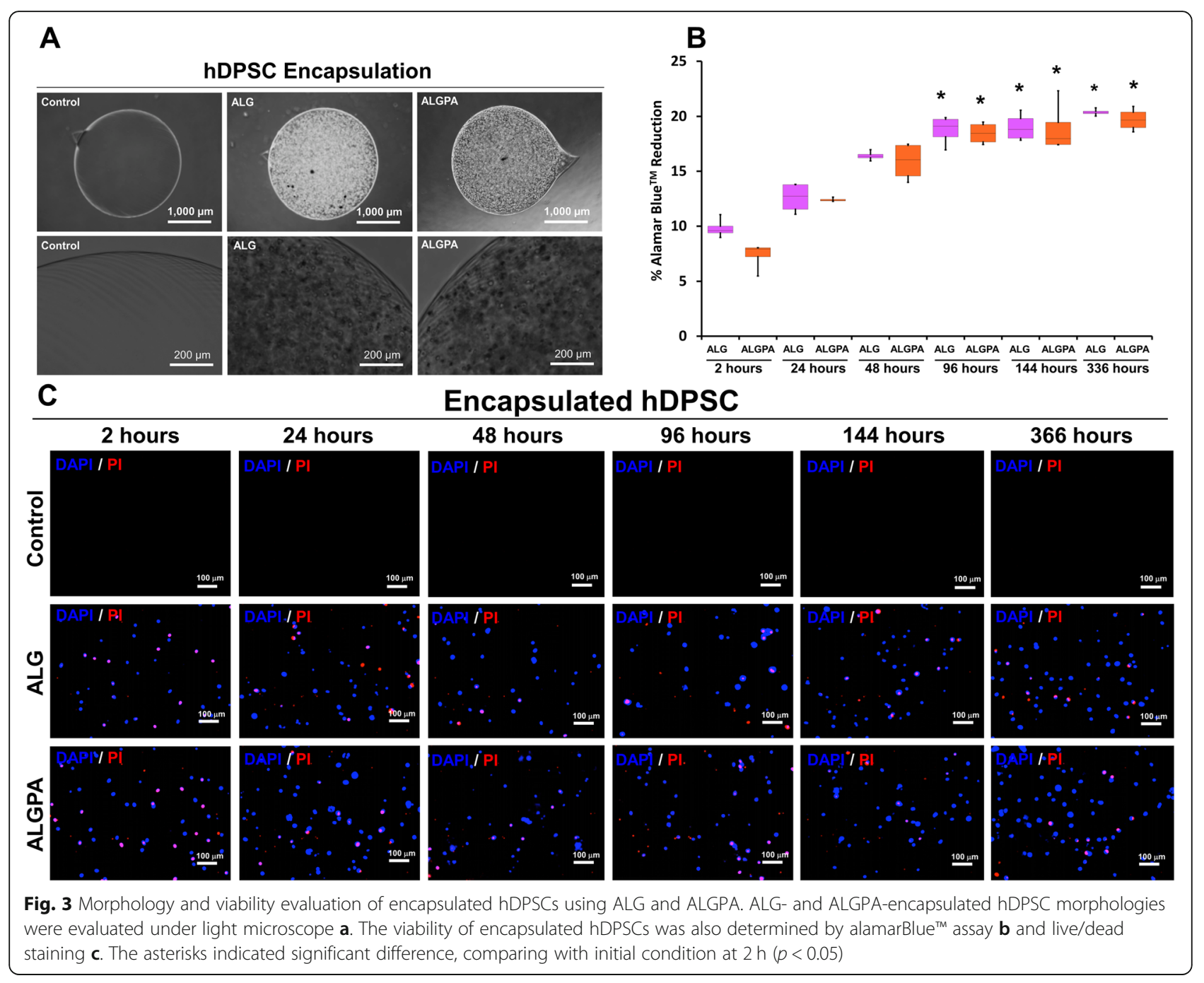

\section{Discussion}

The concept of cell encapsulation was first introduced almost nine decades ago, unfortunately, some clinical trials regarding the application of cell encapsulation have not led any approval for clinical application [24]. Currently, stem cell-based diabetes therapy offers promising strategy for T1DM and eliminate the obstacles of Edmonton protocols [25]. Encapsulation platform can be served to provide viable allogeneic or xenogeneic cells for its purpose [24].

In this study, both ALG and ALGPA encapsulations were validated. The encapsulation method in this study was based on the manual nozzle extrusion as hDPSCderived IPCs were extruded through needle as a nozzle tip. The size of needle plays an important role since the suitable needle size should be fulfilled to avoid the cell aggregate damage [26]. In present study, needle size $22 \mathrm{G}$ with the inner diameter $0.413 \mathrm{~mm}$ was chosen because it provided suitable inner diameter for generated hDPSC-derived IPC size. Permeability is one of important factor for cell encapsulation application [27]. The ALG and ALGPA permeability against glucose and insulin was reported in this study. Similar studies demonstrated the permeability of alginate using mouse insulinoma and glucose-responsive rat cell line. The results of these studies reported that encapsulation of both cell lines could keep the ability of insulin secretion in response to extra-capsular glucose stimulation [28, 29]. Gautier et al. (2011) reported that glucose, ammonia, vitamin B12 and another low to middle molecular weight substance can easily diffuse across the alginate [30]. The results regarding bead swelling assay showed that, both encapsulation by ALG and ALGPA were relatively stable. Assessment of bead swelling was aimed to determine the stability of the beads. In some conditions, alginate beads can swell resulted in the increasing of porosity and bead damage [31]. The swelling behaviour can occur mainly due to the osmotic factors. In PBS, high concentration of $\mathrm{Na}^{+}$can cause bead swelling, but in some studies, alginate beads showed the 


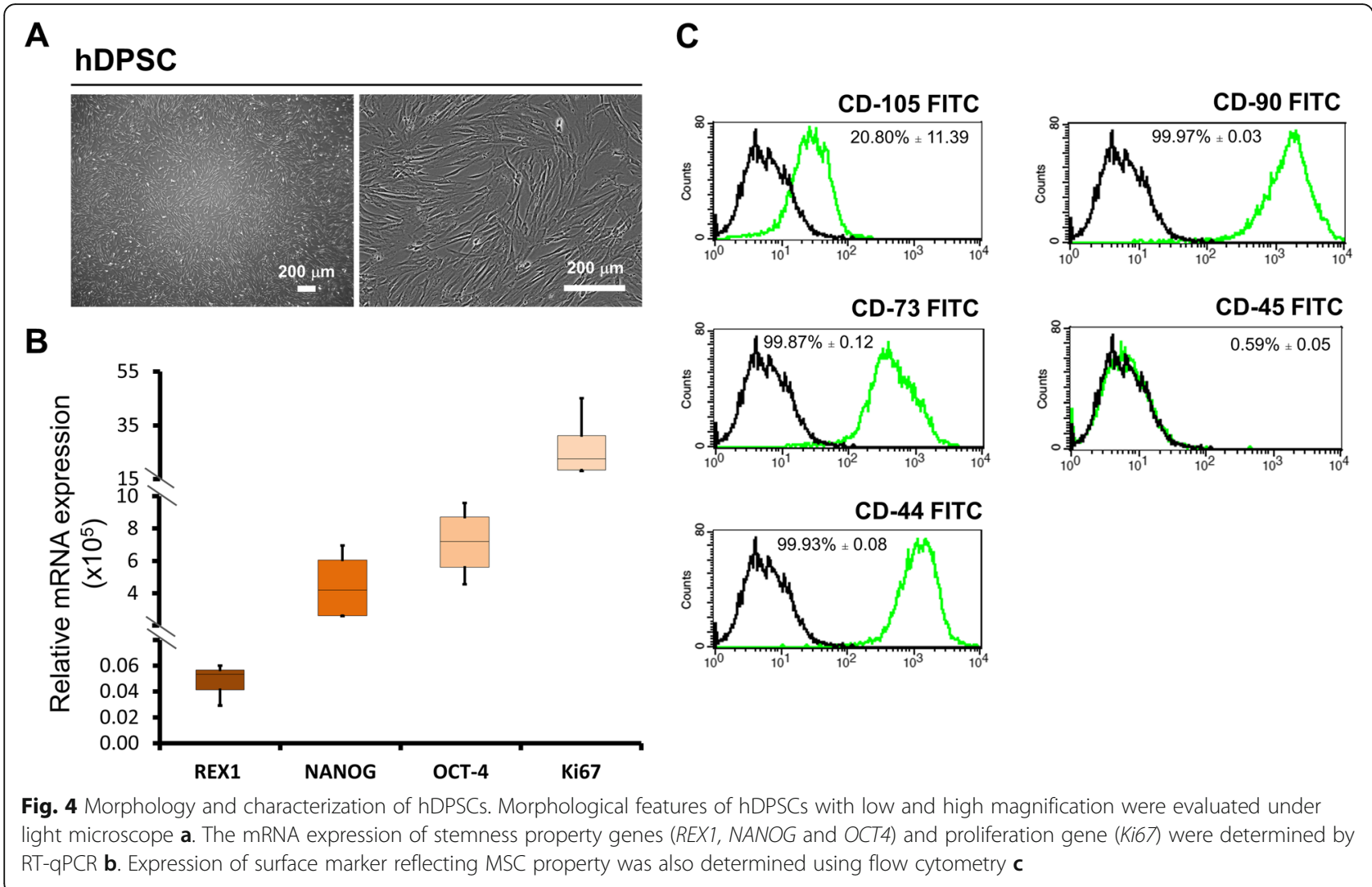

elasticity without showing membrane breakage [31]. In this experiment, high purity of alginate was employed to avoid over-swelling. The substances (i.e. proteins or endotoxins) that could increase the chemical potential of the solvent (negative charge) inside the capsule were not detected. Capsule deformation can occur by the rapid change of the environment. In consequence, the adaptation to a new environment is occurred to achieved the equilibrium of chemical potential of the solvent inside and outside the capsule [32]. In this study, pore morphology was not reported, however similar study with the same alginate type and ionic crosslink solution showed that concentration of $0.5-1 \%$ alginate solution could produce a bead with pore diameter approximately $7.2-8.0 \mathrm{~nm}$ which inhibited $21-25$ $\mathrm{kDa}$ of dextran and $78-103 \mathrm{kDa}$ of protein including immunoglobulin G [33]. In addition, the pore size of the beads can be reduced by increasing the alginate concentration [34].

In the present study, biocompatibility of both encapsulation ALG and ALGPA was assessed. The alamarBlue ${ }^{\mathrm{Tm}}$ assay, a redox indicator, was employed in this study. In three-dimensional (3D) culture system using alginate matrix, choosing the most reliable and precise assay to assess the viability plays an important role. Tetrazolium salt-based assay is widely used to evaluate the cell viability in two-dimensional (2D) culture system, however the highly toxic of DMSO or $\mathrm{HCl} /$ isopropanol used in the assay led an obstacle [35]. Moreover, multiple metabolic reactions in both cytoplasm and mitochondria can be assessed by alamarBlue ${ }^{\mathrm{Tm}}$ assay. This assay is based on the oxidation reduction caused by nicotanimide adenine dinucleotide phosphate hydrogen (NADPH), flavine adenine dinucleotide hydrogen $\left(\mathrm{FADH}_{2}\right)$, flavine adenine mononucleotide hydrogen $\left(\mathrm{FMNH}_{2}\right)$, nicotinamide adenine dinucleotide hydrogen (NADH), cytochromes and all cellular respiration metabolic reaction [36]. During the first $48 \mathrm{~h}$ post-encapsulation, the metabolic activity of hDPSCs was slightly increase. It might cause by the absorption and ion exchange was slow due to the encapsulation compare with 2D culture system. Cell-to-cell communication was also limited by this platform, consequently the cells need longer time for acclimatization [37]. Further, after $96 \mathrm{~h}$ postencapsulation the metabolic activity of hDPSCs was relatively stable. The evidence from another study showed that alginate encapsulation limited the cell proliferation and remained the cell into G0 stage [38]. Moreover, qualitative observation incorporating live/dead staining visualized similar condition. More numerous viable cells were observed more visible compared with non-viable cells after $96 \mathrm{~h}$ post-encapsulation. 

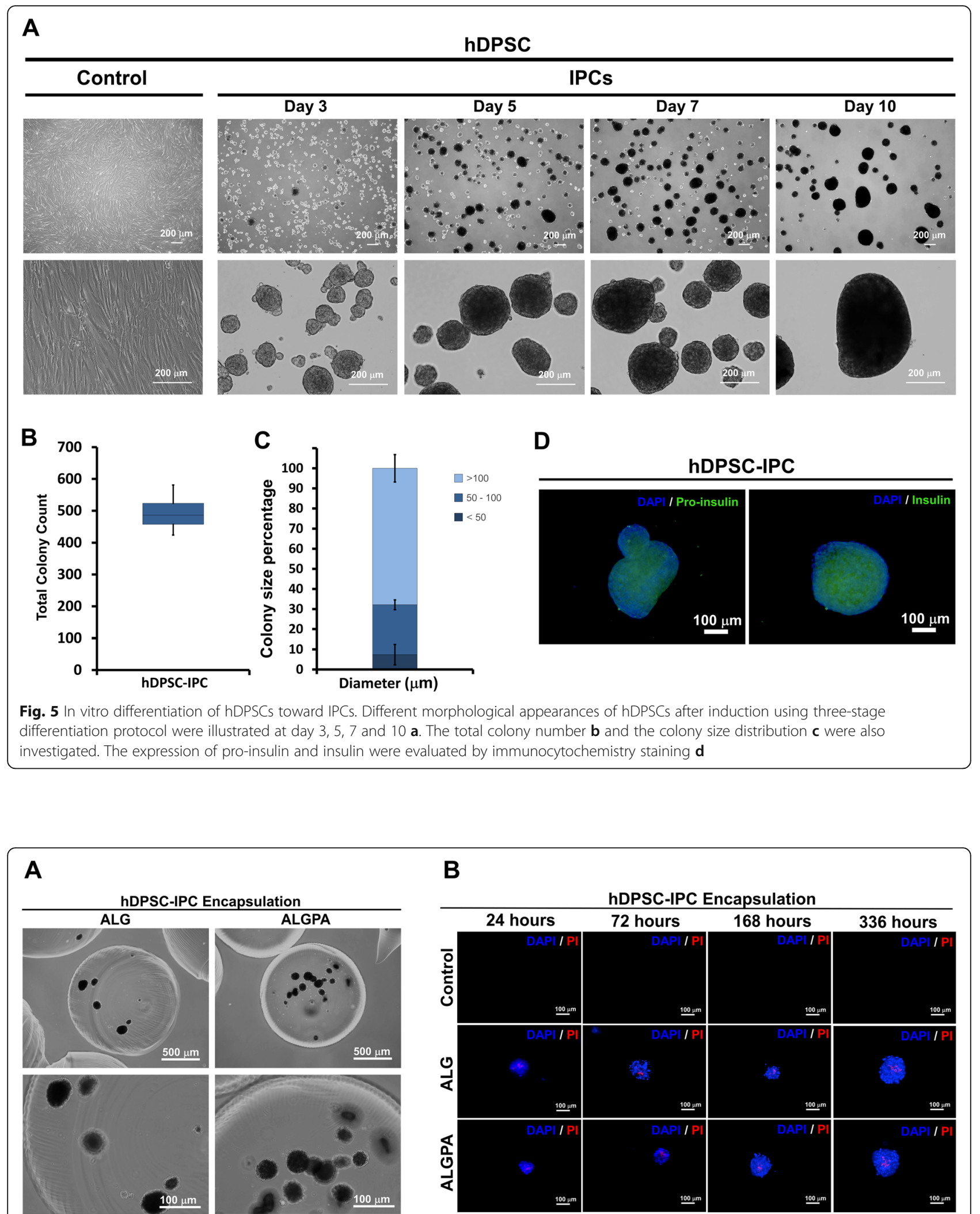

B

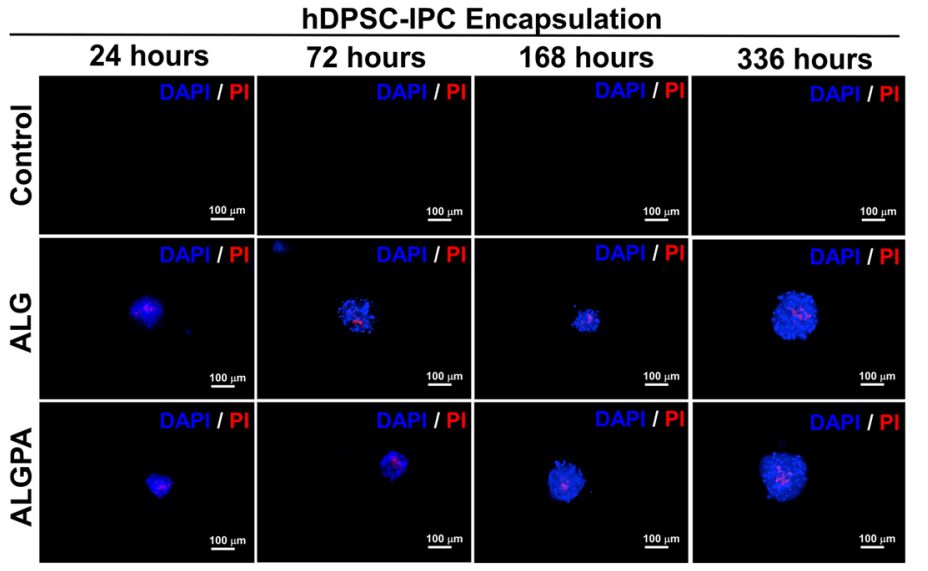

Fig. 6 Morphology and viability evaluation of encapsulated hDPSC-derived IPCs using ALG and ALGPA. Encapsulated hDPSC-derived IPCS morphologies in both ALG and ALGPA were ilustrated $\mathbf{a}$. The viability evaluation of encapsulated hDPSC-derived IPCs was also determined by live/dead staining $\mathbf{b}$ 


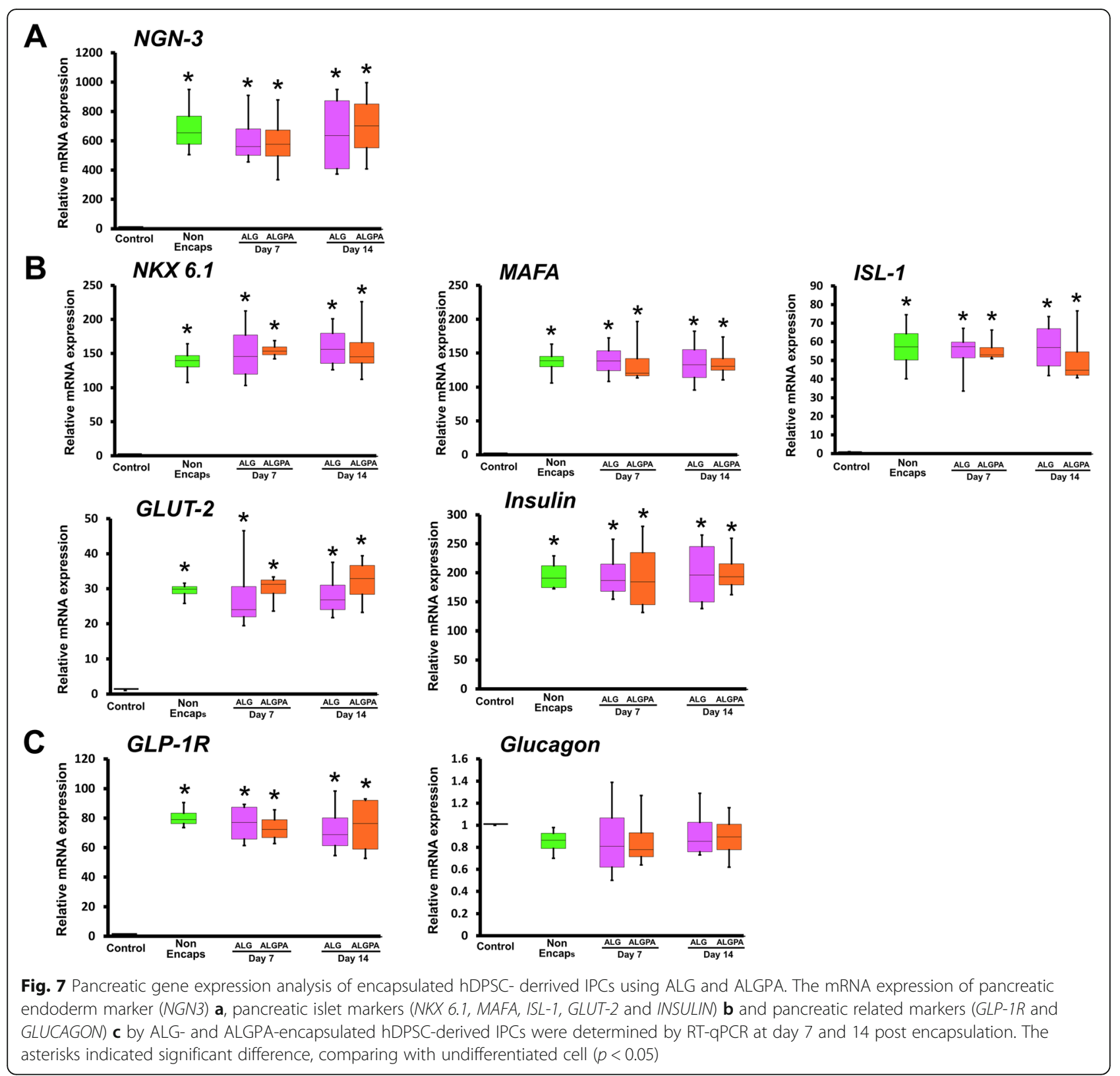

Based on The International Society for Cellular Therapy, the minimum criteria of MSCs were established in 2005. The criteria that should be fulfilled for MSCs included showing fibroblastoid in morphology, adhering in culture plate/flasks under normal culture condition and exhibiting CD73, CD44, CD90 and CD105 surface markers, whereas lacking express of CD45 marker [39]. These minimum criteria were fulfilled by the hDPSCs used in this study. The results of present study were consistent as previous studies that all of MSCs surface markers (CD73, CD44, CD90 and CD105) could be detected in hDPSCs [13, 40]. In addition, pluripotency transcription factors REX1, NANOG and OCT4 were expressed, which was in agreement with previous study conducted by Shivakumar et al. (2019) [41].

Currently, various transdifferentiation protocols of IPCs were reported. Non integrative methods are widely used in MSC-based differentiation protocol, in comparison with integrative methods, where foreign sequences were transduced into host genome are mainly used in induced pluripotent stem cells (iPSCs) [42]. Further, the risk of tumor formation and gene alteration still become the concern regarding safety aspect in clinical application [43]. However, several studies reported the safety aspect of adenoviral and Sendai viral integrative methods [44]. In the present study, non-integrative method using small molecules and peptides was employed for IPC 


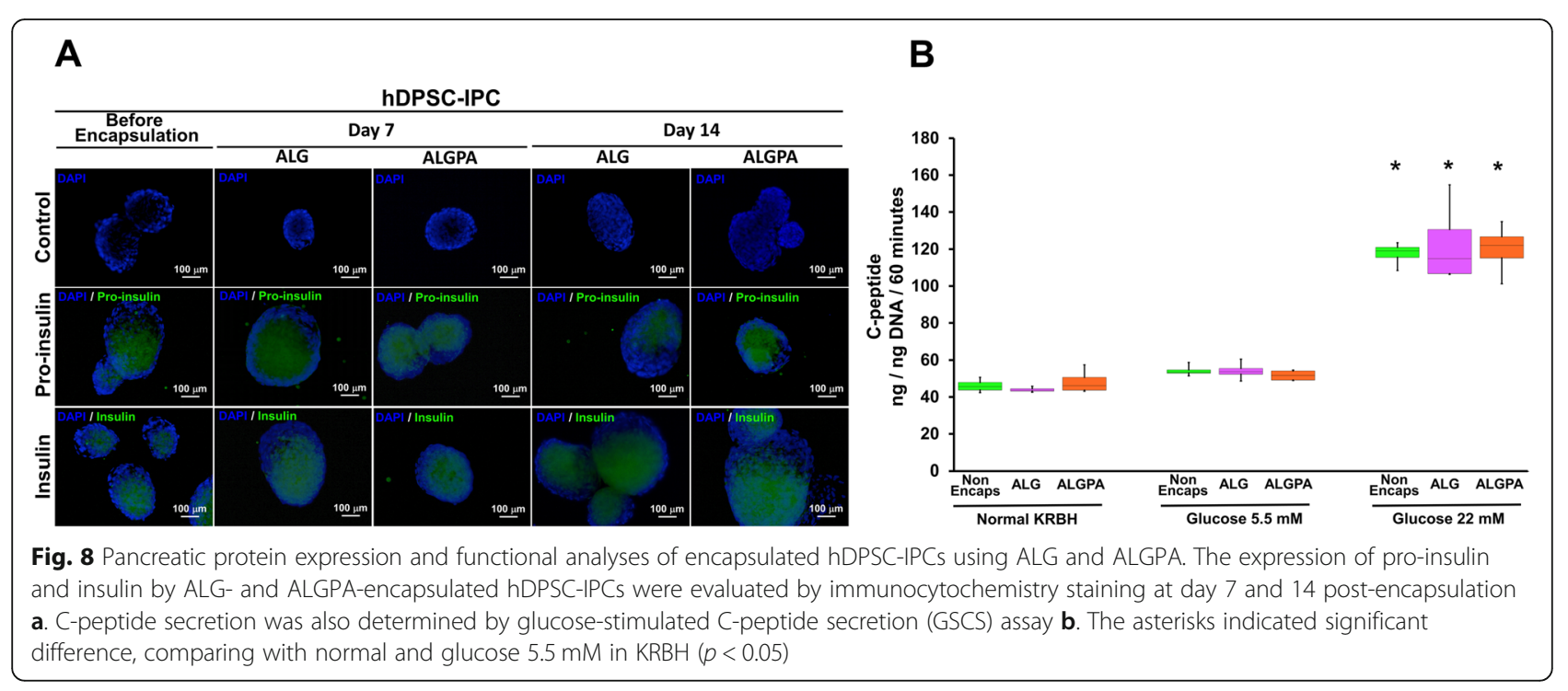

induction. In MSC-based protocols, two main step IPC differentiation were involved. The initial stage, MSCs were induced into pancreatic progenitor followed by $\beta$ cell maturation [45]. However, three-stage differentiation protocol was involved in this study. The initial stage of IPC differentiation was the induction of hDPSCs into definitive endoderm incorporated the combining activin $\mathrm{A}$ and sodium butyrate. A pioneer study reported the successful of the murine adipose-derived stem cells (ASCs) induction into definitive endoderm by using these combinations of small molecules. The results was confirmed by the expression of definitive endoderm protein markers SOX17, Foxa2, HNF-1 $\beta$, also gene markers Foxa2, CK-19 and GATA-4 [46]. Definitive endoderm differentiation also was achieved in hESCs after activin A treatment [47]. L-taurine was employed in the pancreatic endoderm differentiation stage. Similar substance was used for murine ASC differentiation toward pancreatic endoderm [46] and human placenta-derived mesenchymal stem cells (hPDMSCs) [48]. In murine ASC study incorporated physiological dose of L-Taurine, the gene expression of PDX-1, NGN3, NeuroD, Pax4 and NKX2.2 was achieved in day 5 post induction [46]. In this study, NGN3 expression was noted at day 5 . Final step of $\beta$-cell maturation was achieved by adding combination of small molecules and peptides i.e. high dose of L-taurine, nicotinamide and glucagon-like peptide (GLP)-1. The $\beta$-cell-related markers, NKX6.1, MAFA, ISL-1, GLUT-2 and INSULIN were expressed in hDPSC-derived IPCs. PDX1 and NKX6.1 are important transcription factors for $\beta$-cell maturation [49]. In this study, the matured and functional $\beta$-cell still could be achieved in the absence of PDX1 expression, it might caused by the expression of NKX6.1 that could maintain $M A F A$ as a transcription factor for insulin gene expression [44]. Additionally, GLP-1 was reported to increase and stabilize the expression of INSULIN mRNA, subsequently the secretion and stimulation of insulin was enhanced $[44,46]$.

In the present study, qualitative in vitro viability assessment of encapsulated hDPSC-derived IPCs in ALG and ALGPA showed that both encapsulation platform could provide suitable environment for hDPSC-derived IPCs. The essential requirements for cell culture i.e. porosity, stability and permeability were fulfilled by alginate [50]. Consistent results by several studies were reported that pancreatic islet, ESC- and iPSC-derived IPC encapsulation using alginate could maintain the viability both in vivo and in vitro [51-56]. Another study on pancreatic islet cryopreservation incorporated alginate encapsulation reported that alginate encapsulation could maintain both viability and functionality of pancreatic islets [57]. According to the functionality evaluation of hDPSC-derived IPC encapsulation in ALG and ALGPA, the results of this study showed that this encapsulation platform could maintain the expression of pancreatic endoderm and pancreatic $\beta$-cell gene markers at least for 14 days. In undifferentiated ESC and iPSC encapsulation study, post-encapsulation induction in alginate could enhance both gene and protein expression of mature $\beta$-cell markers (PDX1, MAFA and INSULIN) compared to induction in tissue culture plastic (2D system) [51, 54]. However, in MSC-derived IPC study using trabecular meshwork-derived MSCs (TM-MSCs), the mature and functional IPCs in tissue culture plates and alginate microfiber induction did not show significant difference [50]. In addition, encapsulation of differentiated cells (mature $\beta$-cell) was remained difficulties. Study in hESC-derived IPCs, showed that mature $\beta$-cell encapsulation viability still could be maintained, but some 
mature phenotype (insulin secretion) was slightly decreased [54]. Post-encapsulation induction of undifferentiated hESCs resulted in adequate mature $\beta$-cell. However, in vitro differentiation of post-encapsulated hESCs seemed impractical for clinical application since adequate amount of mature $\beta$-cell was difficult to achieve in static culture system [54]. Moreover, the contact of undifferentiated cells under induction media should be minimized to avoid the antigen contamination from dead cells [51]. Beside the beneficial aspect of encapsulation in providing immunoisolation properties, currently, the cell encapsulation technology has been used to treat some diseases i.e. cardiac disease, hepatic disease and bone impairment [58-63] by using several biomaterials i.e. gelatin methacrylate [58], poly (3-hydroxybutyrate) [59], sodium alginate, poly (ethylene glycol) [61], poly (lactic-co-glycolic acid) [63] and poly(N-isopropylacrylamide-co-acrylic acid) or P (NIPAM-AA) [60]. To date, commercially available and FDA approved of encapsulation technology to cure type I DM is not available. Some private companies i.e. Living Cell Technology (DIABECELL $^{\circ}$ ), Sernova Corp. (Their Cell Pouch System ${ }^{\mathrm{Tw}}$ ), ViaCyte $\left(\right.$ PEC-Encap $\left.{ }^{\mathrm{m}}\right)$ and Beta- $\mathrm{O}_{2}$-Technology $\left(\beta\right.$ - Air $^{\circ}$ device) are still conducting US Phase I/II clinical studies. Unfortunately, among these technologies, MSC-derived IPCs have not been reported to use as the cell source. They are using xenogenic porcine-derived islets, allo-islets, hESC-derived pancreatic endocrine cells and iPSCderived IPCs respectively [64]. This present study demonstrated for the first time regarding the mature MSCderived IPC encapsulation. In both encapsulation by ALG and ALGPA, intracellular pro-insulin and insulin expression were detected at day 7 and 14 postencapsulation. These results were consistent with the pancreatic endoderm and pancreatic islet marker gene expression maintained by ALG and ALGPA encapsulation. Finally, the functional property of encapsulated hDPSC-derived IPCs in both ALG and ALGPA was confirmed by the ability of glucose-responsive C-peptide secretion.

\section{Conclusion}

In summary, this study is firstly demonstrating the hDPSC-derived IPC encapsulation in alginate and alginate/pluronic F127. The results from this study suggested that, in both encapsulation platform, the viability and functionality of hDPSC-IPCs could be maintained. However, the role of pluronic F127 in this study was not clearly shown. Further, in vivo study needs to be conducted to evaluate the role of pluronic F127 regarding the ability to enhance angiogenesis, to avoid extra capsular cellular overgrowth and related factors for successful of transplantation.

\section{Materials and methods}

\section{hDPSC isolation and culture}

Human DPSCs were isolated from human dental pulp tissues of extracted premolars and molars according to wisdom teeth issues under patients' informed consents and ethical approval from the Human Research Ethic Committee, Faculty of Dentistry, Chulalongkorn University (HREC-DCU 2018/054). Tissue explant technique was used, based on previous protocol [13]. Cells were seeded and maintained in high glucose Dulbecco's Modified Eagle Medium (DMEM; Thermo Fisher Scientific Corporation, USA) with supplementation of $1 \%$ of AntibioticAntimycotic (Thermo Fisher Scientific Corporation, USA), $1 \%$ GlutaMAX ${ }^{\mathrm{mu}}$ (Thermo Fisher Scientific Corporation, USA), and $10 \%$ fetal bovine serum (FBS) (Thermo Fisher Scientific Corporation, USA) under $37^{\circ} \mathrm{C}$ in humidified environment with $5 \% \mathrm{CO}_{2}$ condition. Culture medium was changed every $48 \mathrm{~h}$. Cells were subculture when $80 \%$ confluence reached. Four different cell lines in passage $2-5$ were used in the experiments.

\section{hDPSC characterization}

hDPSCs were characterized according cell morphology, stemness and proliferative mRNA marker expression, and surface marker analysis. Cell morphology was captured by phase-contrast microscope. RT-qPCR was used to analysed mRNA marker expression regarding stemness property (REX1, NANOG, and OCT4) and proliferative marker (Ki67). Cells were then characterized by flow cytometry for MSC surface markers. Briefly, the cells were stained with FITC-conjugated anti-human $\mathrm{CD} 105^{+}$antibody (Bio Legend, California, USA), FITC-conjugated anti-human $\mathrm{CD}^{+}{ }^{+}$(Ecto-5' -nucleotidase) antibody (Bio Legend, California, USA), FITC-conjugated anti-human $\mathrm{CD}^{+}$ (Thy1) antibody (Bio Legend, California, USA), FITCconjugated anti-human $\mathrm{CD} 44^{+}$antibody (Bio Legend, California, USA), and FITC-conjugated anti-human CD45 antibody (Bio Legend, California, USA). FITC-conjugated Mouse IgG1א isotype control (FC) antibody (Bio Legend, California, USA) was used as an isotype control for this assay. The assay was performed by using FACScallibur flow cytometer with CellQuest software (BD Bioscience, New Jersey, USA).

\section{In vitro differentiation of IPCs}

IPC differentiation was performed by using 10 days 3step differentiation protocol as performed by Sawangmake et al. (2014) (13). Briefly, $1 \times 10^{6}$ of hDPSCs were seeded in $60 \mathrm{~mm}$ non-treated culture dish (Eppendorf, Hamburg, Germany) as a single cell suspension. The cells were maintained in serum-free medium (SFM)-A for 3 days, SFM-B for 2 days and SFM-C for 5 days and the medium were changed every $48 \mathrm{~h}$. The medium used in this experiment were SFM-DMEM (Thermo Fisher 
Scientific Corporation, USA) with different supplementation. The supplementation of each medium were respectively as follows; SFM-A: 1\% BSA (Cohn fraction $\mathrm{V}$, fatty acid free; Sigma, Missouri, USA), 1X insulintransferrin-selenium (ITS) (Invitrogen, USA), 4 nM activin A (Sigma, Sigma, Missouri, USA), $1 \mathrm{nM}$ sodium butyrate (Sigma, Missouri, USA), and $50 \mu \mathrm{M}$ betamercaptoethanol (Sigma, Missouri, USA); SFM-B: $1 \%$ BSA, 1X ITS, and $0.3 \mathrm{mM}$ taurine (Sigma, Missouri, USA); and SFM C: $1.5 \%$ BSA, $1 \mathrm{X}$ ITS, $3 \mathrm{mM}$ taurine, $100 \mathrm{nM}$ glucagon-like peptide (GLP)-1 (Sigma, Missouri, USA), $1 \mathrm{mM}$ nicotinamide (Sigma, Missouri, USA), and $1 \mathrm{x}$ non-essential amino acids (NEAAs) (Sigma, Missouri, USA).

\section{Alginate and alginate/pluronic F127 bead fabrication and morphological observation}

Alginate bead fabrication was performed by manual extruding method using plastic syringe with different needle size (22G, 24G and 26G). In brief, 2.0\% (w/v) sodium alginate (Sigma, Missouri, USA) solution was extruded into $100 \mathrm{mM} \mathrm{CaCl}$ gelling solution for $5 \mathrm{~min}$. The crosslinked process was performed under stirring condition to avoid beads coalescence during polymerization. The beads were removed and were washed in Kreb-Ringer HEPES (KRH) buffer ( $\mathrm{pH}$ 7.22) containing $2.5 \mathrm{mM} \mathrm{CaCl}, 132 \mathrm{mM} \mathrm{NaCl}, 4.7 \mathrm{mM} \mathrm{KCl}$, $1.2 \mathrm{mM} \quad \mathrm{MgCl}_{2} \cdot 6 \mathrm{H}_{2} \mathrm{O}, 25 \mathrm{mM}$ HEPES and 2.52 $\mathrm{CaCl}_{2} \cdot 2 \mathrm{H}_{2} \mathrm{O}$ for $5 \mathrm{~min}$ under stirring condition. For double coating, the alginate beads were incubated in $30 \%$ (w/v) pluronic F127 (Sigma, Missouri, USA) solution for $3 \mathrm{~min}$ at room temperature. Pluronic F127 coated beads subsequently wash 3 times by using phosphate-buffered saline (PBS) $\mathrm{pH}$ 7.4. All the protocols were performed under sterile condition. Generated beads were maintained in PBS under $37^{\circ} \mathrm{C}$ in humidified environment with $5 \% \quad \mathrm{CO}_{2}$ condition for 28 days. Morphological evaluation was performed under inverted microscope (EVOS - Invitrogen, California, USA). The beads diameter was analysed by using Image J software (National Institute of Health, Maryland, USA).

\section{Modified-transwell diffusion study}

Costar brand (Corning, New York, USA) 24-well $8 \mu \mathrm{m}$ pore size transwells were used in this study. Transwell insert barrier were modified by coating using $1.5 \mathrm{~mm}$ alginate and/or $1.0 \mathrm{~mm}$ pluronic F127 in thickness. Transwell insert barriers were assembled into respective well, subsequently $100 \mu \mathrm{L}$ of $22.2 \mathrm{mM}$ glucose solution or insulin standard solution were filled in the upper compartment while $600 \mu \mathrm{L}$ PBS in the lower compartment. The transwell culture plate were maintain in $37^{\circ} \mathrm{C}$ incubator for diffusion study. After 5, 15, 30, and 60 min-incubation, the solution in the lower compartments were collected for glucose quantification using glucose liquocolor GOD-PAP method (Human, Wiesbaden, Germany) and insulin level quantification after 30 and 60 min incubation by using human Insulin ELISA kit (EMD Millipore, Burlington, Massachusetts, USA).

\section{hDPSC and hDPSC-derived IPC encapsulation}

Single cell hDPSCs at a concentration of $1 \times 10^{6}$ cell $/ \mathrm{mL}$ and cell aggregates of hDPSC-derived IPCs from previous protocol were resuspended in $2.0 \%$ alginate solution. The encapsulation of hDPSCs and hDPSC-derived IPCs were performed by using manual extruding method as described in previous part. Subsequentially after encapsulation protocol, the beads were removed and maintained in normal medium for encapsulated hDPSCs and SFM-C for encapsulated hDPSC-derived IPCs under $37^{\circ} \mathrm{C}$ in humidified environment with $5 \% \mathrm{CO}_{2}$ condition. The culture medium will be changed every $48 \mathrm{~h}$ until the following analyses.

\section{Cell viability assay}

Encapsulated hDPSCs and hDPSC-derived IPCs were evaluated for their viability using qualitative live/dead fluorescent staining kit, The NUCLEAR-ID ${ }^{\circ}$ Blue/Red cell viability reagent (GFP-CERTIFIED ${ }^{\circ}$ ) (Enzo Life Science, Farmingdale, New York, USA), according to the manufacture protocol. The results were interpreted using fluorescent microscope equipped with Carl Zeiss ${ }^{\mathrm{Tm}}$ Apoptome. 2 apparatus (Carl Zeiss, California, USA). Furthermore, the alamarBlue ${ }^{\text {тx }}$ (Invitrogen, California, USA) were used to evaluate the encapsulated hDPSCs. In brief, encapsulated hDPSCs were maintained in normal medium containing $10 \%(\mathrm{v} / \mathrm{v})$ alamarBlue ${ }^{\mathrm{rt}}$ for $20 \mathrm{~h}$. To determine the percent reduction of alamarBlue ${ }^{\mathrm{in}}$, the solution was measured using spectrophotometer at 570 and $600 \mathrm{~nm}$ wavelength.

\section{Capsule dissolution}

Prior to post-encapsulation evaluation, ALG and ALGPA encapsulated hDPSC-derived IPCs were dissolved by incubating in dissolving buffer (0.1 M EDTA and $0.2 \mathrm{M}$ $\mathrm{C}_{6} \mathrm{H}_{5} \mathrm{Na}_{2} \mathrm{O}_{7} .2 \mathrm{H}_{2} \mathrm{O}$, pH 7.4) for $5 \mathrm{~min}$ in $37^{\circ} \mathrm{C}$. hDPSCderived IPCs from degraded alginate beads were washed in PBS three times 3 min each, and processed for further analysis (RT-qPCR and immunocytochemistry staining).

\section{Reverse transcription-quantitative real time polymerase chain reaction ( $R T-q P C R$ )}

TRIzol $^{\text {TM }}$ reagent (Invitrogen, Callifornia, USA) was used for cellular RNA extraction, subsequentially the cDNA was obtained from $1 \mu \mathrm{g}$ RNA using reverse transcriptase enzyme kit (Promega, Wisconsin, USA). Reverse transcription-quantitative real time PCR (RT-qPCR) using 
FastStart ${ }^{\ominus}$ Essential DNA Green Master (Roche Diagnostic, Risch-Rotkreuz, Switzerland) was performed to detect the gene expression by CFX96 ${ }^{\text {ma }}$ real time PCR detection system (Bio-Rad, California, USA). The mRNA value will be presented as relative mRNA expression by normalized to $18 \mathrm{~S}$ ribosomal RNA and the control. The formula $2^{-\Delta \Delta C t}$ will be used to calculate normalization and fold change. The primer sequences were shown in Table 1.

\section{Immunocytochemistry staining}

Cell colonies of hDPSC-derived IPCs were fixed in cold methanol, subsequently $0.1 \%$ Triton $^{\circ}$-X100 (Sigma, Missouri, USA) in PBS to permeabilized the sample, and then were incubated with $10 \%$ donkey serum in PBS for $1 \mathrm{~h}$ for background reducing. The primary antibodies used in this experiment were mouse anti-human proinsulin (EMD Millipore, Burlington, Massachusetts, USA) and mouse anti-human insulin (EMD Millipore, Burlington, Massachusetts, USA) at the dilution 1:100. FITC-conjugated goat anti-mouse IgG (Abcam, Cambridge, United Kingdom) at dilution 1:1000 were used as secondary antibody. DAPI $(0.1 \mu \mathrm{g} / \mathrm{mL})$ was used to counterstain the nucleus. Interpretation of this assay were performed by analyzing under fluorescent microscope equipped with Carl Zeiss ${ }^{\mathrm{Tn}}$ Apoptome.2 apparatus (Carl Zeiss, California, USA).

\section{Glucose stimulated C-peptide secretion (GSCS) assay}

Glucose-stimulated C-peptide secretion (GSCS) assay was performed at day 14 post encapsulation by incubating encapsulated hDPSC-derived IPCs in normal KRH $\mathrm{NaHCO}_{3}(\mathrm{KRBH})$ pH $7.22(120 \mathrm{mM} \mathrm{NaCl}, 5 \mathrm{mM} \mathrm{KCl}$, $2.5 \mathrm{mM} \mathrm{CaCl} 2.2 \mathrm{H}_{2} \mathrm{O}, 1.1 \mathrm{mM} \mathrm{MgCl} 2.6 \mathrm{H}_{2} \mathrm{O}$ and $25 \mathrm{mM}$ $\mathrm{NaHCO}_{3}$ ), $5.5 \mathrm{mM}$ of glucose anhydrous (Sigma, Missouri, USA) in KRBH, or $22 \mathrm{mM}$ glucose anhydrous (Sigma, Missouri, USA) in KRBH for $60 \mathrm{~min}$ in each buffer solution. Enzyme-linked immunosorbent assay (ELISA) was used to quantified C-peptide level by using human C-peptide ELISA kit (EMD Millipore, Burlington, Massachusetts, USA) based on manufacturing protocol. Subsequently, encapsulated hDPSCderived IPCs were disolved using dissolving buffer, cell collony were collected and DNA extraction was perform by using DNeasy Blood and Tissue Kits (Qiagen, Venlo, Netherlands). The level of C-peptide was normalized with the total DNA (ng) and stimulation time (minutes).

Table 1 List of Primers

\begin{tabular}{|c|c|c|c|c|}
\hline Genes & Accession number & Forward Primer Reverse Primer & Length (bp) & $\operatorname{Tm}\left({ }^{\circ} \mathrm{C}\right)$ \\
\hline$\overline{N A N O G}$ & NM_024865.4 & $\begin{array}{l}\text { 5' - ATGCCTCACACGGAGACTGT - 3' } \\
5^{\prime}-\text { AAGTGGGTTGTTGCCTTT - 3' }\end{array}$ & 103 & $\begin{array}{l}61.19 \\
57.31\end{array}$ \\
\hline OCT-4 & NM_002701.6 & $\begin{array}{l}5^{\prime}-\text { TCGAGAACCGAGTGAGAGG - 3' } \\
5^{\prime}-\text { GAACCACACTCGGACCACA - 3' }\end{array}$ & 125 & $\begin{array}{l}58.14 \\
59.56\end{array}$ \\
\hline REX-1 & NM_174900.5 & $\begin{array}{l}5^{\prime}-\text { TGGGAAAGCGTCGTTGAGA - 3' } \\
5^{\prime}-\text { CACCCTTCAAAAGTGCACCG - 3' }\end{array}$ & 90 & $\begin{array}{l}59.89 \\
59.97\end{array}$ \\
\hline Ki67 & NM_001145966.1 & $\begin{array}{l}5^{\prime}-\text { TCAGAATGGAAGGAAGTCAACTG - 3' } \\
5^{\prime}-\text { TCACTCTCATCAGGGTCAGAAG - 3' }\end{array}$ & 105 & $\begin{array}{l}58.35 \\
58.90\end{array}$ \\
\hline PDX-1 & NM_000209.4 & $\begin{array}{l}5^{\prime}-\text { AAGCTCACGCGTGGAAAGG - 3' } \\
5^{\prime}-\text { GGCCGTGAGATGTACTTGTTG - 3' }\end{array}$ & 145 & $\begin{array}{l}57.89 \\
52.38\end{array}$ \\
\hline$N G N-3$ & NM_020999.3 & $\begin{array}{l}5^{\prime}-\text { CGGTAGAAAGGATGACGCCT - 3' } \\
5^{\prime}-\text { GGTCACTTCGTCTTCCGAGG - 3' }\end{array}$ & 138 & $\begin{array}{l}59.54 \\
60.11\end{array}$ \\
\hline$N K X-6.1$ & NM_006168.2 & $\begin{array}{l}5^{\prime}-\text { TTGGCCTATTCGTTGGGGAT - 3' } \\
5^{\prime}-\text { GTCTCCGAGTCCTGCTTCTTC - 3' }\end{array}$ & 125 & $\begin{array}{l}59.08 \\
60.14\end{array}$ \\
\hline MAFA & NM_201589.3 & $\begin{array}{l}5^{\prime}-\text { GCACATTCTGGAGAGCGAGA - } 3^{\prime} \\
5^{\prime}-\text { TTCTCCTTGTACAGGTCCCG - 3' }\end{array}$ & 102 & $\begin{array}{l}59.83 \\
58.74\end{array}$ \\
\hline ISL-1 & NM_002202.2 & $\begin{array}{l}5^{\prime}-\text { TCCCTATGTGTTGGTTGCGG - 3' } \\
5^{\prime}-\text { TTGGCGCATTTGATCCCGTA - 3' }\end{array}$ & 200 & $\begin{array}{l}60.32 \\
60.39\end{array}$ \\
\hline GLUT-2 & NM_000340.1 & $\begin{array}{l}5^{\prime}-\text { GGTTTGTAACTTATGCCTAAG - 3' } \\
5^{\prime} \text { - GCCTAGTTATGCATTGCAG - 3' }\end{array}$ & 211 & $\begin{array}{l}52.25 \\
54.24\end{array}$ \\
\hline INSULIN & NM_000207.2 & $\begin{array}{l}5^{\prime} \text { - CCGCAGCCTTTGTGAACCAACA - 3' } \\
5^{\prime}-\text { TTCCACAATGCCACGCTTCTGC - 3' }\end{array}$ & 215 & $\begin{array}{l}64.34 \\
64.45\end{array}$ \\
\hline$G L P-1 R$ & NM_002062.4 & $\begin{array}{l}5^{\prime}-\text { TCGCTGTGAAAATGAGGAGGA - 3' } \\
5^{\prime}-\text { TCACTCCCGCTCTGTGTTIG - 3' }\end{array}$ & 189 & $\begin{array}{l}59.38 \\
60.25\end{array}$ \\
\hline GLUCAGON & NM_002054.4 & $\begin{array}{l}5^{\prime}-\text { TTATTTGGAAGGCCAAGCTGC - 3' } \\
5^{\prime}-\text { GTCTGCGGCCAAGTTCTTCA - 3' }\end{array}$ & 110 & $\begin{array}{l}59.45 \\
60.88\end{array}$ \\
\hline 185 & NR_003286.2 & $\begin{array}{l}5^{\prime}-\text { GTGATGCCCTTAGATGTCC }-3^{\prime} \\
5^{\prime}-\text { CCATCCAATCGGTAGTAGC - 3' }\end{array}$ & 233 & $\begin{array}{l}55.04 \\
54.86\end{array}$ \\
\hline
\end{tabular}




\section{Statistical analysis}

The results of this study were presented as box plot with whisker bar. Non-parametric statistical analysis and four replicates for each cell type $(n=4)$ were used in the study. The statistical analysis was performed by using SPSS Statistics. To compare two independent groups, the Mann Whitney U test was employed, while Kruskal Wallis test and pairwise comparison were used for three or more group comparison. Statistically significant difference was recognized when $p$-value $<0.05$.

\section{Abbreviations}

IPC: Insulin-producing cell; hDPSC: Human dental pulp stem cell; ESCs: Embryonic stem cells; MSCs: Mesenchymal stem cells; BM-MSCs: Bone marrow-derived mesenchymal stem cells; SHED: Stem cells from human exfoliated deciduous teeth; RT-qPCR: Real time quantitative polymerase chain reaction; FITC: Fluorescein isothiocyanate; NADPH: Nicotanimide adenine dinucleotide phosphate hydrogen; $\mathrm{FADH}_{2}$ : Flavine adenine dinucleotide hydrogen; $\mathrm{FMNH}_{2}$ : Flavine adenine mononucleotide hydrogen; NADH: Nicotinamide adenine dinucleotide hydrogen; iPSCs: Induced pluripotent stem cells; ASCs: Adipose-derived stem cells; hPDMSCs: Human placenta-derived mesenchymal stem cells; TM-MSCs: Trabecular meshworkderived mesenchymal stem cells

\section{Acknowledgements}

The authors thank Professor Kaywalee Chatdarong (DVM, MSc, PhD, DTBT), Department of Obstetrics, Gynaecology and Reproduction, Faculty of Veterinary Science, Chulalongkorn University, for providing support on qPCR analysis; Ms. Daneeya Chaikiawkeaw (BSc, MSc), Center of Excellence for Regenerative Dentistry, Faculty of Dentistry, Chulalongkorn University, for helping on microplate analysis; Mr. Noppadol Sa-ard-lam (BSC, MSc), Department of Periodontology, Faculty of Dentistry, Chulalongkorn University, for supporting on flow cytometry analysis; and the Veterinary Stem Cell and Bioengineering Innovation Center (VSCBIC) (http://www.cuvscbic.com/), Faculty of Veterinary Science, Chulalongkorn University, for providing research facility support.

\section{Authors' contributions \\ SK performed most of the experiments and wrote the manuscript; WR performed some experiments; SY provided the discussion and materials for encapsulation; TO and PP provided the discussion and cells; SS wrote and edited the manuscript; CS conceived the presented idea, designed experiments, wrote research grant and edited the manuscript. All authors read and approved the final manuscript.}

\section{Funding}

SK was supported by Combined Scholarship between the 100th Anniversary Chulalongkorn University Fund for Doctoral Scholarship and Scholarship for International Graduate Students of Chulalongkorn University, the 90th Anniversary Chulalongkorn University Fund, and Veterinary Clinical Stem Cell and Bioengineering Research Unit, Ratchadaphiseksomphot Endowment Fund, Chulalongkorn University. WR was supported by the 100th Anniversary Chulalongkorn University Fund for Doctoral Scholarship, the 90th Anniversary Chulalongkorn University Fund, and Veterinary Clinical Stem Cell and Bioengineering Research Unit, Ratchadaphiseksomphot Endowment Fund, Chulalongkorn University. TO and PP were supported by Chulalongkorn Academic Advancement into Its second Century Project. SY and SS were supported by Ratchadaphiseksomphot Endowment Fund, Chulalongkorn University. CS was supported by research supporting grant of the Faculty of Veterinary Science, Chulalongkorn Academic Advancement into Its second Century Project, Veterinary Clinical Stem Cell and Bioengineering Research Unit, Ratchadaphiseksomphot Endowment Fund, Chulalongkorn University, and Government Research Fund.

\section{Availability of data and materials}

The datasets used and/or analyzed during the current study are available from the corresponding author on reasonable request.

\section{Ethics approval and consent to participate}

Research involving human material was performed in accordance with the Declaration of Helsinki and approved by the Human Research Ethic Committee, Faculty of Dentistry, Chulalongkorn University. Human DPSCs were isolated from human dental pulp tissues of extracted premolars and molars according to wisdom teeth issues under patients' informed consents under an approved protocol (HREC-DCU 2018/054).

\section{Consent for publication}

This manuscript contains no details, or videos relating to an individual person so that this section is not applicable.

\section{Competing interests}

The authors declare that they have no competing interests.

\section{Author details}

${ }^{1}$ International Graduate Course in Veterinary Science and Technology, Faculty of Veterinary Science, Chulalongkorn University, Bangkok 10330, Thailand. ${ }^{2}$ Veterinary Stem Cell and Bioengineering Innovation Center (VSCBIC), Veterinary Pharmacology and Stem Cell Research Laboratory, Faculty of Veterinary Science, Chulalongkorn University, Bangkok 10330, Thailand. ${ }^{3}$ Research Affairs, Faculty of Medicine, Chulalongkorn University, Bangkok 10330, Thailand. ${ }^{4}$ Excellence Center for Advanced Therapy Medicinal Products, King Chulalongkorn Memorial Hospital, Bangkok 10330, Thailand. ${ }^{5}$ Department of Anatomy, Faculty of Dentistry, Chulalongkorn University, Bangkok 10330, Thailand. ${ }^{6}$ Center of Excellence in Regenerative Dentistry, Faculty of Dentistry, Chulalongkorn University, Bangkok 10330, Thailand. ${ }^{7}$ Department of Veterinary Anatomy, Faculty of Veterinary Science, Chulalongkorn University, Bangkok 10330, Thailand. ${ }^{8}$ Veterinary Clinical Stem Cell and Bioengineering Research Unit, Faculty of Veterinary Science, Chulalongkorn University, Bangkok 10330, Thailand. ${ }^{9}$ Department of Pharmacology, Faculty of Veterinary Science, Chulalongkorn University, Bangkok 10330, Thailand.

Received: 24 April 2020 Accepted: 13 August 2020

Published online: 24 August 2020

\section{References}

1. Danaei G, Finucane MM, Lu Y, Singh GM, Cowan MJ, Paciorek CJ, et al. National, regional, and global trends in fasting plasma glucose and diabetes prevalence since 1980: systematic analysis of health examination surveys and epidemiological studies with 370 country-years and 2.7 million participants. Lancet. 2011;378(9785):31-40. Epub 2011/06/28. doi: https://doi. org/10.1016/s0140-6736(11)60679-x. PubMed PMID: 21705069.

2. Cho NH, Shaw JE, Karuranga S, Huang Y, da Rocha Fernandes JD, Ohlrogge AW, et al. IDF diabetes atlas: global estimates of diabetes prevalence for 2017 and projections for 2045. Diabetes Res Clin Pract 2018;138:271-281. Epub 2018/03/03. doi: https://doi.org/10.1016/j.diabres.2018.02.023. PubMed PMID: 29496507.

3. Handelsman Y, Bloomgarden ZT, Grunberger G, Umpierrez G, Zimmerman RS, Bailey TS, et al. American association of clinical endocrinologists and american college of endocrinology - clinical practice guidelines for developing a diabetes mellitus comprehensive care plan - 2015. Endocr Pract. 2015;21 Suppl 1:1-87. Epub 2015/04/15. doi: https://doi.org/10.4158/ ep15672.Gl. PubMed PMID: 25869408; PubMed Central PMCID: PMCP MC4959114.

4. Kalra S, Mukherjee JJ, Venkataraman S, Bantwal G, Shaikh S, Saboo B, et al. Hypoglycemia: The neglected complication. Indian J Endocrinol Metab. 2013;17(5):819-834. Epub 2013/10/02. doi: https://doi.org/10.4103/22308210.117219. PubMed PMID: 24083163; PubMed Central PMCID: PMCP MC3784865.

5. Shapiro AM, Ricordi C, Hering BJ, Auchincloss H, Lindblad R, Robertson RP, et al. International trial of the Edmonton protocol for islet transplantation. N Engl J Med 2006;355(13):1318-1330. Epub 2006/09/29. doi: https://doi.org/ 10.1056/NEJMoa061267. PubMed PMID: 17005949.

6. Brennan DC, Kopetskie HA, Sayre PH, Alejandro R, Cagliero E, Shapiro AM, et al. Long-term follow-up of the Edmonton protocol of islet transplantation in the United States. Am J Transplant 2016;16(2):509-517. Epub 2015/10/04. doi: https://doi.org/10.1111/ajt.13458. PubMed PMID: 26433206.

7. Schiesser JV, Wells JM. Generation of beta cells from human pluripotent stem cells: are we there yet? Ann N Y Acad Sci. 2014;1311:124-137. Epub 
2014/03/13. doi: https://doi.org/10.1111/nyas.12369. PubMed PMID: 24611778; PubMed Central PMCID: PMCPMC4144703.

8. Chmielowiec J, Borowiak M. In vitro differentiation and expansion of human pluripotent stem cell-derived pancreatic progenitors. Rev Diabet Stud. 2014; 11(1):19-34. Epub 2014/08/26. doi: https://doi.org/10.1900/rds.2014.11.19 PubMed PMID: 25148365: PubMed Central PMCID. PMCPMC4295798.

9. Kim HJ, Park JS. Usage of Human Mesenchymal Stem Cells in Cell-based Therapy: Advantages and Disadvantages. Dev Reprod. 2017;21(1):1-10. Epub 2017/05/10. doi: https://doi.org/10.12717/dr.2017.21.1.001. PubMed PMID: 28484739; PubMed Central PMCID: PMCPMC5409204.

10. Gauthaman K, Fong C-Y, Suganya C-A, Subramanian A, Biswas A, Choolani $M$, et al. Extra-embryonic human Wharton's jelly stem cells do not induce tumorigenesis, unlike human embryonic stem cells. Reprod Biomed Online. 2012;24(2):235-46. https://doi.org/10.1016/j.rbmo.2011.10.007.

11. Xie QP, Huang H, Xu B, Dong X, Gao SL, Zhang B, et al. Human bone marrow mesenchymal stem cells differentiate into insulin-producing cells upon microenvironmental manipulation in vitro. Differentiation. 2009:77(5): 483-491. Epub 2009/06/10. doi: https://doi.org/10.1016/j.diff.2009.01.001. PubMed PMID: 19505629.

12. Govindasamy V, Abdullah AN, Ronald VS, Musa S, Aziz ZACA, Zain RB, et al. Inherent differential propensity of dental pulp stem cells derived from human deciduous and permanent teeth. J Endod. 2010;36(9):1504-15 https://doi.org/10.1016/j.joen.2010.05.006.

13. Sawangmake C, Nowwarote $N$, Pavasant $P$, Chansiripornchai $P$, Osathanon T. A feasibility study of an in vitro differentiation potential toward insulinproducing cells by dental tissue-derived mesenchymal stem cells. Biochem Biophys Res Commun 2014;452(3):581-587. Epub 2014/09/03. doi: https:// doi.org/10.1016/j.bbrc.2014.08.121. PubMed PMID: 25181343.

14. Cui X, Chen L, Xue T, Yu J, Liu J, Ji Y, et al. Human umbilical cord and dental pulp-derived mesenchymal stem cells: biological characteristics and potential roles in vitro and in vivo. Mol Med Rep. 2015;11(5):3269-3278. Epub 2015/01/17. doi: https://doi.org/10.3892/mmr.2015.3198. PubMed PMID: 25591506; PubMed Central PMCID: PMCPMC4368085.

15. Park YJ, Cha S, Park YS. Regenerative Applications Using Tooth Derived Stem Cells in Other Than Tooth Regeneration: A Literature Review. Stem Cells Int. 2016;2016:9305986. Epub 2016/01/23. doi: https://doi.org/10.1155/2016/ 9305986. PubMed PMID: 26798366; PubMed Central PMCID: PMCPMC4699044.

16. Luke AM, Patnaik R, Kuriadom S, Abu-Fanas S, Mathew S, Shetty KP. Human dental pulp stem cells differentiation to neural cells, osteocytes and adipocytes-An in vitro study. Heliyon. 2020;6(1):e03054. Epub 2020/02/12. doi: https://doi.org/10.1016/j.heliyon.2019.e03054. PubMed PMID: 32042932; PubMed Central PMCID: PMCPMC7002807.

17. Xu B, Fan D, Zhao Y, Li J, Wang Z, Wang J, et al. Three-Dimensional Culture Promotes the Differentiation of Human Dental Pulp Mesenchymal Stem Cells Into Insulin-Producing Cells for Improving the Diabetes Therapy. Front Pharmacol. 2019;10:1576. Epub 2020/02/11. doi: https://doi.org/10.3389/ fphar.2019.01576. PubMed PMID: 32038250; PubMed Central PMCID: PMCP MC6993085

18. Korsgren O. Islet encapsulation: physiological possibilities and limitations. Diabetes. 2017;66(7):1748-1754. Epub 2017/06/24. doi: https://doi.org/10. 2337/db17-0065. PubMed PMID: 28637827.

19. Kuncorojakti S, Srisuwatanasagul S, Kradangnga K, Sawangmake C. Insulinproducing cell transplantation platform for veterinary practice. Front Vet Sci. 2020;7:4.

20. Wang N, Adams G, Buttery L, Falcone FH, Stolnik S. Alginate encapsulation technology supports embryonic stem cells differentiation into insulinproducing cells. J Biotechnol. 2009;144(4):304-12. https://doi.org/10.1016/j. jbiotec.2009.08.008.

21. Paredes Juárez GA, Spasojevic M, Faas MM, de Vos P. Immunological and Technical Considerations in Application of Alginate-Based Microencapsulation Systems. Front Bioeng Biotechnol. 2014;2:26. https://doi. org/10.3389/fbioe.2014.00026.

22. Bhujbal SV, de Haan B, Niclou SP, de Vos P. A novel multilayer immunoisolating encapsulation system overcoming protrusion of cells. Sci Rep. 2014;4:6856. doi: https://doi.org/10.1038/srep06856 https://www.nature. com/articles/srep06856 - supplementary-information.

23. Diniz IM, Chen C, Xu X, Ansari S, Zadeh HH, Marques MM, et al. Pluronic F127 hydrogel as a promising scaffold for encapsulation of dental-derived mesenchymal stem cells. J Mater Sci Mater Med. 2015;26(3):153. Epub 2015/ 03/17. doi: https://doi.org/10.1007/s10856-015-5493-4. PubMed PMID: 25773231; PubMed Central PMCID: PMCPMC4477746.
24. Ashimova A, Yegorov S, Negmetzhanov B, Hortelano G. Cell Encapsulation Within Alginate Microcapsules: Immunological Challenges and Outlook. Front Bioeng Biotechnol. 2019;7:380. Epub 2019/12/19. doi: https://doi.org/ 10.3389/fbioe.2019.00380. PubMed PMID: 31850335; PubMed Central PMCID: PMCPMC6901392

25. Dimitrioglou N, Kanelli M, Papageorgiou E, Karatzas T, Hatziavramidis D. Paving the way for successful islet encapsulation. Drug Discov Today. 2019; 24(3):737-48. https://doi.org/10.1016/j.drudis.2019.01.020.

26. Hoesli CA, Kiang RLJ, Raghuram K, Pedroza RG, Markwick KE, Colantuoni AMR, et al. Mammalian Cell Encapsulation in Alginate Beads Using a Simple Stirred Vessel. J Visual Exp. 2017;(124). Epub 2017/07/18. doi: https://doi.org/ 10.3791/55280. PubMed PMID: 28715390; PubMed Central PMCID: PMCP MC5608521.

27. Farina M, Alexander JF, Thekkedath U, Ferrari M, Grattoni A. Cell encapsulation: Overcoming barriers in cell transplantation in diabetes and beyond Adv Drug Deliv Rev 2018. Epub 2018/05/03. doi: https://doi.org/10. 1016/j.addr.2018.04.018. PubMed PMID: 29719210.

28. Bertolotti A, Borgogna M, Facoetti A, Marsich E, Nano R. The effects of alginate encapsulation on NIT-1 insulinoma cells: viability, growth and insulin secretion. Vivo 2009;23(6):929-935. Epub 2009/12/22. PubMed PMID: 20023235.

29. Duruksu G, Polat S, Kayis L, Ekimci Gurcan N, Gacar G, Yazir Y. Improvement of the insulin secretion from beta cells encapsulated in alginate/poly-Lhistidine/alginate microbeads by platelet-rich plasma. Turk J Biol. 2018;42(4): 297-306. Epub 2019/03/01. doi: https://doi.org/10.3906/biy-1802-13. PubMed PMID: 30814893; PubMed Central PMCID: PMCPMC6392160.

30. Gautier A, Carpentier B, Dufresne M, Vu Dinh Q, Paullier P, Legallais C. Impact of alginate type and bead diameter on mass transfers and the metabolic activities of encapsulated C3A cells in bioartificial liver applications. Eur Cells Mat. 2011;21:94-106. Epub 2011/01/27. doi: https:// doi.org/10.22203/ecm.v021a08. PubMed PMID: 21267945.

31. Montanucci P, Terenzi S, Santi C, Pennoni I, Bini V, Pescara T, et al. Insights in Behavior of Variably Formulated Alginate-Based Microcapsules for Cell Transplantation. BioMed Res Int. 2015;2015:965804. Epub 2015/06/17. doi: https://doi.org/10.1155/2015/965804. PubMed PMID: 26078974; PubMed Central PMCID: PMCPMC4452837.

32. Hong W, Liu Z, Suo Z. Inhomogeneous swelling of a gel in equilibrium with a solvent and mechanical load. Int J Solids Struct. 2009:46(17):3282-9. https://doi.org/10.1016/j.jijolstr.2009.04.022.

33. Dembczynski R, Jankowski T. Determination of pore diameter and molecular weight cut-off of hydrogel-membrane liquid-core capsules for immunoisolation. J Biomater Sci Polym Ed. 2001;12(9):1051-8. https://doi. org/10.1163/156856201753252552.

34. Goh CH, Heng PWS, Chan LW. Alginates as a useful natural polymer for microencapsulation and therapeutic applications. Carbohydr Polym. 2012; 88(1):1-12. doi: https://doi.org/10.1016/j.carbpol.2011.11.012.

35. Bonnier F, Keating ME, Wrobel TP, Majzner K, Baranska M, Garcia-Munoz A et al. Cell viability assessment using the Alamar blue assay: a comparison of 2D and 3D cell culture models. Toxicol in Vitro 2015;29(1):124-131. Epub 2014/10/11. doi: https://doi.org/10.1016/j.tiv.2014.09.014. PubMed PMID: 253 00790.

36. Ahmed SA, Gogal RM, Jr., Walsh JE. A new rapid and simple non-radioactive assay to monitor and determine the proliferation of lymphocytes: an alternative to [3H] thymidine incorporation assay. J Immunol Methods 1994; 170(2):211-224. Epub 1994/04/15. doi: https://doi.org/10.1016/00221759(94)90396-4. PubMed PMID: 8157999.

37. Sarker B, Rompf J, Silva R, Lang N, Detsch R, Kaschta J, et al. Alginate-based hydrogels with improved adhesive properties for cell encapsulation. Int J Biol Macromol 2015;78:72-78. Epub 2015/04/08. doi: https://doi.org/10.1016/ j.jibiomac.2015.03.061. PubMed PMID: 25847839.

38. Razavi S, Khosravizadeh Z, Bahramian H, Kazemi M. Time-Dependent Effect of Encapsulating Alginate Hydrogel on Neurogenic Potential. Cell J. 2015; 17(2):304-311. Epub 2015/07/23. doi: https://doi.org/10.22074/cellj.2016. 3736. PubMed PMID: 26199909; PubMed Central PMCID: PMCPMC4503844.

39. Horwitz EM, Le Blanc K, Dominici M, Mueller I, Slaper-Cortenbach I, Marini FC, et al. Clarification of the nomenclature for MSC: the International Society for Cellular Therapy position statement. Cytotherapy. 2005;7(5):393-395. Epub 2005/10/21. doi: https://doi.org/10.1080/14653240500319234. PubMed PMID: 16236628.

40. Karamzadeh R, Eslaminejad MB, Aflatoonian R. Isolation, characterization and comparative differentiation of human dental pulp stem cells derived from 
permanent teeth by using two different methods. J Visual Exp. 2012;(69). Epub 2012/12/05. doi: https://doi.org/10.3791/4372. PubMed PMID: 23208006; PubMed Central PMCID: PMCPMC3566710.

41. Shivakumar SB, Lee HJ, Son YB, Bharti D, Ock SA, Lee SL, et al. In vitro differentiation of single donor derived human dental mesenchymal stem cells into pancreatic beta cell-like cells. Biosci Rep. 2019;39(5). Epub 2019/ 04/25. doi: https://doi.org/10.1042/bsr20182051. PubMed PMID: 31015367; PubMed Central PMCID: PMCPMC6527933.

42. Nakanishi M, Otsu M. Development of Sendai virus vectors and their potential applications in gene therapy and regenerative medicine. Curr Gene Ther. 2012;12(5):410-416. Epub 2012/08/28. doi: https://doi.org/10. 2174/156652312802762518. PubMed PMID: 22920683; PubMed Central PMCI D: PMCPMC3504922

43. Schlaeger TM, Daheron L, Brickler TR, Entwisle S, Chan K, Cianci A, et al. A comparison of non-integrating reprogramming methods. Nat Biotechnol. 2015;33(1):58-63. Epub 2014/12/02. doi: https://doi.org/10.1038/nbt.3070. PubMed PMID: 25437882; PubMed Central PMCID: PMCPMC4329913.

44. Zhou YY, Zeng F. Integration-free methods for generating induced pluripotent stem cells. Genomics Proteomics Bioinform. 2013;11(5):284-287. Epub 2013/10/15. doi: https://doi.org/10.1016/j.gpb.2013.09.008. PubMed PMID: 24121200; PubMed Central PMCID: PMCPMC4357834.

45. Pavathuparambil Abdul Manaph N, Sivanathan KN, Nitschke J, Zhou XF, Coates PT, Drogemuller CJ. An overview on small molecule-induced differentiation of mesenchymal stem cells into beta cells for diabetic therapy. Stem Cell Res Ther. 2019;10(1):293. Epub 2019/09/25. doi: https:// doi.org/10.1186/s13287-019-1396-5. PubMed PMID: 31547868; PubMed Central PMCID: PMCPMC6757413.

46. Chandra V, G S, Phadnis S, Nair PD, Bhonde RR. Generation of pancreatic hormone-expressing islet-like cell aggregates from murine adipose tissuederived stem cells. Stem Cells 2009;27(8):1941-1953. Epub 2009/06/23. doi: https://doi.org/10.1002/stem.117. PubMed PMID: 19544426.

47. Massumi M, Pourasgari F, Nalla A, Batchuluun B, Nagy K, Neely E, et al. An Abbreviated Protocol for In Vitro Generation of Functional Human Embryonic Stem Cell-Derived Beta-Like Cells. PLoS One. 2016:11(10): e0164457. Epub 2016/10/19. doi: https://doi.org/10.1371/journal.pone. 0164457. PubMed PMID: 27755557; PubMed Central PMCID: PMCP MC5068782

48. Kadam S, Muthyala S, Nair P, Bhonde R. Human placenta-derived mesenchymal stem cells and islet-like cell clusters generated from these cells as a novel source for stem cell therapy in diabetes. Rev Diab Stud. 2010;7(2):168-182. Epub 2010/11/10. doi: https://doi.org/10.1900/rds.2010.7. 168. PubMed PMID: 21060975; PubMed Central PMCID: PMCPMC2989789.

49. Abdelalim EM, Emara MM. Advances and challenges in the differentiation of pluripotent stem cells into pancreatic beta cells. World I Stem Cells. 2015; 7(1):174-181. Epub 2015/01/27. doi: https://doi.org/10.4252/wjsc.v7.11.174. PubMed PMID: 25621117; PubMed Central PMCID: PMCPMC4300928.

50. Barati G, Nadri S, Hajian R, Rahmani A, Mostafavi H, Mortazavi Y, et al. Differentiation of microfluidic-encapsulated trabecular meshwork mesenchymal stem cells into insulin producing cells and their impact on diabetic rats. J Cell Physiol 2019;234(5):6801-6809. Epub 2018/10/15. doi: https://doi.org/10.1002/jcp.27426. PubMed PMID: 30317587.

51. Richardson T, Kumta PN, Banerjee I. Alginate encapsulation of human embryonic stem cells to enhance directed differentiation to pancreatic isletlike cells. Tissue Eng Part A. 2014;20(23-24):3198-3211. Epub 2014/06/03. doi: https://doi.org/10.1089/ten. TEA.2013.0659. PubMed PMID: 24881778; PubMed Central PMCID: PMCPMC4259202

52. Alagpulinsa DA, Cao JJL, Driscoll RK, Sirbulescu RF, Penson MFE, Sremac M, et al. Alginate-microencapsulation of human stem cell-derived beta cells with CXCL12 prolongs their survival and function in immunocompetent mice without systemic immunosuppression. Am J Transplant 2019;19(7): 1930-1940. Epub 2019/02/13. doi: https://doi.org/10.1111/ajt.15308. PubMed PMID: 30748094

53. Westenfelder C, Gooch A, Hu Z, Ahlstrom J, Zhang P. Durable Control of Autoimmune Diabetes in Mice Achieved by Intraperitoneal Transplantation of "Neo-Islets" Three-Dimensional Aggregates of Allogeneic Islet and "Mesenchymal Stem Cells". Stem Cells Transl Med. 2017;6(7):1631-1643. Epub 2017/05/04. doi: https://doi.org/10.1002/sctm.17-0005. PubMed PMID: 28467694; PubMed Central PMCID: PMCPMC5689775.

54. Vethe H, Legøy TA, Abadpour S, Strand BL, Scholz H, Paulo JA, et al. Encapsulation boosts islet-cell signature in differentiating human induced pluripotent stem cells via integrin signalling. BioRxiv. 2019:791442. https:// doi.org/10.1101/791442.

55. Montanari E, Meier RPH, Mahou R, Seebach JD, Wandrey C, Gerber-Lemaire $S$, et al. Multipotent mesenchymal stromal cells enhance insulin secretion from human islets via $\mathrm{N}$-cadherin interaction and prolong function of transplanted encapsulated islets in mice. Stem Cell Res Ther. 2017;8(1):199. Epub 2017/10/01. doi: https://doi.org/10.1186/s13287-017-0646-7. PubMed PMID: 28962589; PubMed Central PMCID: PMCPMC5622460.

56. Liu Q, Chiu A, Wang LH, An D, Zhong M, Smink AM, et al. Zwitterionically modified alginates mitigate cellular overgrowth for cell encapsulation. Nat Commun. 2019;10(1):5262. Epub 2019/11/22. doi: https://doi.org/10.1038/ s41467-019-13238-7. PubMed PMID: 31748525; PubMed Central PMCID: PMCPMC6868136.

57. Kojayan GG, Flores A, Li S, Alexander M, Lakey JRT. Cryopreserved alginateencapsulated islets can restore Euglycemia in a diabetic animal model better than cryopreserved non-encapsulated islets. Cell Med. 2019;11: 2155179019876641. https://doi.org/10.1177/2155179019876641.

58. Saini H, Navaei A, Van Putten A, Nikkhah M. 3D cardiac microtissues encapsulated with the co-culture of cardiomyocytes and cardiac fibroblasts. Adv Healthcare Mat 2015;4(13):1961-1971. Epub 2015/07/02. doi: https://doi. org/10.1002/adhm.201500331. PubMed PMID: 26129820.

59. Castellano D, Blanes M, Marco B, Cerrada I, Ruiz-Sauri A, Pelacho B, et al. A comparison of electrospun polymers reveals poly (3-hydroxybutyrate) fiber as a superior scaffold for cardiac repair. Stem Cells Dev. 2014;23(13):14791490. Epub 2014/02/26. doi: https://doi.org/10.1089/scd.2013.0578. PubMed PMID: 24564648; PubMed Central PMCID: PMCPMC4066229.

60. Tang J, Cui X, Caranasos TG, Hensley MT, Vandergriff AC, Hartanto Y, et al. Heart Repair Using Nanogel-Encapsulated Human Cardiac Stem Cells in Mice and Pigs with Myocardial Infarction. ACS Nano. 2017;11(10):9738-9749. Epub 2017/09/21. doi: https://doi.org/10.1021/acsnano.7b01008. PubMed PMID: 28929735; PubMed Central PMCID: PMCPMC5656981.

61. Meier RP, Montanari E, Morel P, Pimenta J, Schuurman HJ, Wandrey C, et al. Microencapsulation of hepatocytes and Mesenchymal stem cells for therapeutic applications. Methods Mol Biol 2017;1506:259-271. Epub 2016/ 11/11. doi: https://doi.org/10.1007/978-1-4939-6506-9_18. PubMed PMID: 27830559.

62. Shi X, Wang $Y$, Ren $L$, Huang W, Wang DA. A protein/antibiotic releasing poly (lactic-co-glycolic acid)/lecithin scaffold for bone repair applications. Int J Pharm 2009;373(1-2):85-92. Epub 2009/05/12. doi: https://doi.org/10.1016/ j.ijpharm.2009.02.013. PubMed PMID: 19429292.

63. Kim SH, Kim JE, Kim SH, Jung Y. Substance P/dexamethasone-encapsulated PLGA scaffold fabricated using supercritical fluid process for calvarial bone regeneration. J Tissue Eng Regen Med 2017;11(12):3469-3480. Epub 2017/ 06/02. doi: https://doi.org/10.1002/term.2260. PubMed PMID: 28568973.

64. Santos-Vizcaino E, Orive G, Pedraz JL, Hernandez RM. Clinical applications of cell encapsulation technology. Methods Mol Biol 2020;2100:473-491. Epub 2020/01/16. doi: https://doi.org/10.1007/978-1-0716-0215-7_32. PubMed PMID: 31939144

\section{Publisher's Note}

Springer Nature remains neutral with regard to jurisdictional claims in published maps and institutional affiliations.

Ready to submit your research? Choose BMC and benefit from:

- fast, convenient online submission

- thorough peer review by experienced researchers in your field

- rapid publication on acceptance

- support for research data, including large and complex data types

- gold Open Access which fosters wider collaboration and increased citations

- maximum visibility for your research: over $100 \mathrm{M}$ website views per year

At $\mathrm{BMC}$, research is always in progress.

Learn more biomedcentral.com/submission 